\title{
A Middle American Ameiva, Holcosus festivus (Teiidae), as Prey of the Banded Calico Snake, Oxyrhopus petolarius (Dipsadidae)
}

\author{
Mateo Marín-Martínez ${ }^{1}$, Julián Andrés Rojas-Morales ${ }^{2,3}$, and Román Felipe Díaz-Ayala ${ }^{1}$ \\ ${ }^{1}$ Grupo de Ecología y Diversidad de Anfibios y Reptiles, Facultad de Ciencias Exactas y Naturales, Universidad de Caldas, \\ Manizales, Colombia (mateo2805@hotmail.com) \\ ${ }^{2}$ Ecología Tropical, Instituto de Ciencias Ambientales y Ecológicas, Facultad de Ciencias, Universidad de Los Andes, Mérida, Venezuela \\ ${ }^{3}$ Research Associate, Museo de Historia Natural, Centro de Museos, Universidad de Caldas, Manizales, Caldas, Colombia
}

Snakes are important predators in many terrestrial, aquatic, $\checkmark$ and marine communities, and have evolved several ways to detect, capture, and ingest prey (Alencar et al. 2013; Vitt and Caldwell 2014). Species in the genus Oxyrhopus compose a monophyletic Neotropical group of terrestrial snakes that feed on a wide variety of vertebrates, although lizards and small mammals are the main components of their diets (Duellman 1978; Alencar et al. 2012; Gaiarsa et al. 2013).
The Banded Calico Snake, Oxyrhopus petolarius (Linnaeus 1758), generally is terrestrial and nocturnal, but occasional records document arboreal and diurnal activity. It is widely distributed throughout Central and tropical South America (Lee 1996, 2000; Lynch 2009; McCrainie 2011). In Colombia, this snake occurs in almost all lowland ecoregions from Amazonian rainforests to the dry tropical forests of the upper Cauca River, in the Caribbean lowlands, and the upper
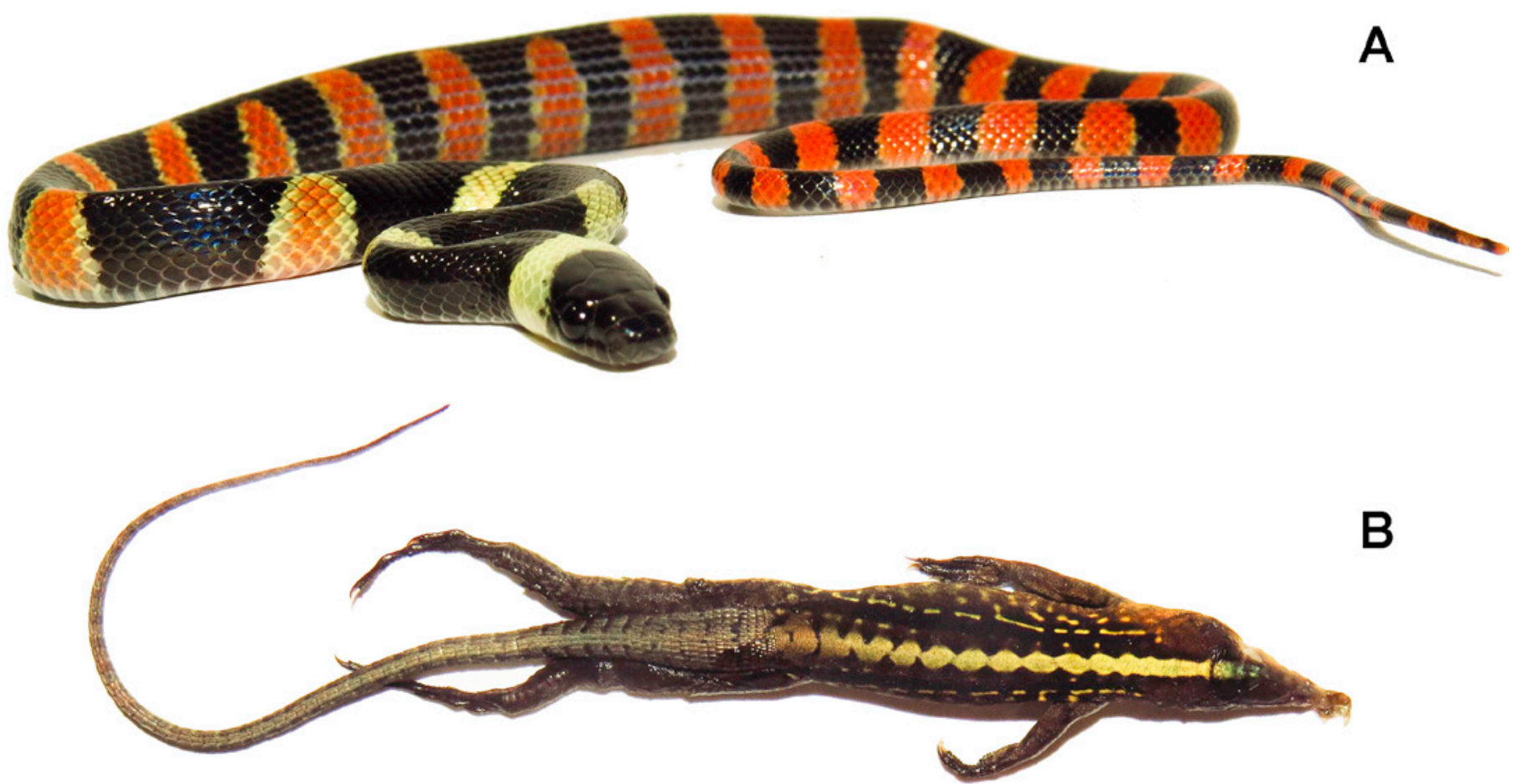

B

Fig. 1. (A) A juvenile female Banded Calico Snake (Oxyrhopus petolarius, MHN-UCa 0268) collected in the village of Berlín, Municipality of Samaná, Department of Caldas, Colombia; note the distended midsection. (B) A juvenile female Middle American Ameiva (Holcosus festivus; MHN-UCa 0267) extracted from the stomach of the snake. 
Magdalena Basin (Lynch 2009). This is a relatively common snake in secondary dry tropical forests as well as in humid lowland forests, but exhibits considerably less forest fidelity than do its Colombian congeners (Lynch 2009). It is a generalist predator, with a diet that includes small mammals, lizards, and birds (Gaiarsa et al. 2013; Nogueira et al. 2013; Caldeira et al. 2014), but occasionally other prey, such as amphibians, other snakes, bird eggs, and bats (Rodríguez-França and Amorim 2012; Gaiarsa et al. 2013). These snakes overpower prey using a presumably weak venom introduced by rear fangs (Lee 1996, 2000), although the venom appears to be highly toxic to anoles (Anolis spp.; Boos 2001). Herein we report an incidence of predation by $O$. petolarius on the Middle American Ameiva, Holcosus festivus (Lichtenstein 1856) in a premontane humid forest in the middle Magdalena River Valley of Colombia.

Holcosus festivus is distributed from Mexico to Colombia at elevations of 100-1,000 $\mathrm{m}$ asl (Köhler 2003). It is an active predator of invertebrates and small vertebrates that usually forages along open forest edges (Vitt and Colli 1994; Vitt and Carvalho 1995; Vitt and Zani 1996). Although these lizards are terrestrial, they can climb trunks of trees and low vegetation to bask or reach prey (Vitt and Zani 1996; Köhler 2003). Peak foraging activity is late morning $(1030-1230 \mathrm{~h})$ and then decreases through the day (Hillman 1969; Vitt and Zani 1996). Lattanzio (2014) noted that escape responses varied with time of day, and that the flight initiation distance (FID) decreased throughout the day, suggesting that lizards might be more vulnerable to predators at night.

At 2128 h on 7 September 2015, we found a juvenile female O. petolarius (SVL $222 \mathrm{~mm}$, TL $66 \mathrm{~mm}$; MHN-UCa 0268; Fig. 1A) perched $102 \mathrm{~cm}$ above the ground and 30 $\mathrm{m}$ from a stream in the village of Berlín, Municipality of Samaná, Department of Caldas, Colombia $\left(5.608767^{\circ} \mathrm{N}\right.$, $-74.955331^{\circ} \mathrm{W}$; WGS84; elevation $650 \mathrm{~m}$ asl). The distended midsection of the snake indicated that it had recently swallowed a prey item. Dissection revealed a juvenile female Holcosus festivus (SVL $45.6 \mathrm{~mm}$, TL $96 \mathrm{~mm}$; MHN-UCa 0267; Fig. 1B) that had been ingested headfirst.

Digestion of the lizard's head was modest, suggesting that it had been caught recently, presumably when inactive. The ratio of prey total length (TL) to predator SVL (0.63) was intermediate; the prey qualifies as type III (sensu Cundall and Greene 2000), which is fusiform, roughly spherical in crosssection, and relatively heavy. This kind of prey invokes a high handling cost and requires an increased gape (Cundall and Greene 2000). Also interesting is the elevated perch of the snake, which might support the hypothesis of Martins (1993), who suggested that some Neotropical snakes, even those that are usually terrestrial, sleep on elevated perches to avoid predation by terrestrial invertebrates. On the ground in the same area, we found a juvenile male Red-tailed Coralsnake, Micrurus mipartitus (Duméril, Bibron, and Duméril, 1854; Elapidae) that was being eaten by ants.
Although this is not the first record of $H$. festivus as prey of $O$. petolarius (see Guyer and Donnelly 2004), it is important because it shows that these species sustain a trophic relationship in different tropical environments, the evidence suggests that the snake encountered the lizard when it was inactive, and the elevated perch assumed by the snake after feeding is supportive of an anti-predator strategy.

\section{Acknowledgements}

We thank ISAGEN S.A E.S.P (contract 47/80) for funding the fieldwork, the Corporación Autónoma Regional de Caldas for granting a collecting permit (Resolution 164 of 2014), Henrique Caldeira Costa and Diogo Borges for supplying relevant literature, and Paulo Sérgio Bernarde (Universidade Federal do Acre) and Teddy Angarita-Sierra (Yoluka ONG) for useful comments that improved the manuscript.

\section{Literature Cited}

Alencar, L.R.V., C.A.B. Galdino, and L.B. Nascimento. 2012. Life history aspects of Oxyrhopus trigeminus (Serpentes:Dipsadidae) from two sites in southeastern Brazil. Journal of Herpetology 46: 9-13.

Alencar, L.R.V., M.P. Gaiarsa, and M. Martins. 2013. The evolution of diet and microhabitat use in pseudoboine snakes. South American Journal of Herpetology 8: 60-66.

Boos, H.E.A. 2001. The Snakes of Trinidad and Tobago. Texas A\&M University Press, College, Station, Texas.

Caldeira, H., D. Borges, and R.A. Feio. 2014. New prey record for the Banded Calico Snake Oxyrhopus petolarius (Serpentes: Dipsadidae). Herpetology Notes 7: 115-118.

Cundall, D. and H.W. Greene. 2000. Feeding in snakes, pp. 293-333. In: K. Schwenk (ed.), Feeding: Form, Function, and Evolution in Tetrapod Vertebrates. Academic Press, San Diego, California.

Duellman, W.E. 1978. The Biology of an Equatorial Herpetofauna in Amazonian Ecuador. University of Kansas Museum of Natural History Miscellaneous Publication 5: 1-352.

Guyer, C. and M.A. Donnelly. 2004. Amphibians and Reptiles of La Selva, Costa Rica, and the Caribbean Slope: A Comprehensive Guide. University of California Press, Berkeley.

Gaiarsa, M.P., L.R.V, Alencar, and M. Martins. 2013. Natural history of pseudoboine snakes. Papéis Avulsos do Zoologia 53: 261-283.

Hillman, P.E. 1969. Habitat specificity in three sympatric species of Ameiva (Reptilia: Teiidae). Ecology 50: 476-481.

Köhler, G. 2003. Reptiles of Central America. Herpeton Verlag, Offenbach, Germany.

Lattanzio, M.S. 2014. Temporal and ontogenic variation in the escape response of Ameiva festiva (Squamata: Teiidae). Phyllomedusa 13: 17-27.

Lee, J.C. 1996. The Amphibians and Reptiles of the Yucatán Peninsula. Cornell University Press, Ithaca, New York.

Lee, J.C. 2000. A Field Guide to the Amphibians and Reptiles of the Maya World. The Lowlands of Mexico, Northern Guatemala, and Belize. Cornell University Press, Ithaca, New York.

Lynch, J.D. 2009. Snakes of the genus Oxyrhopus (Colubridae: Squamata) in Colombia: Taxonomy and geographic variation. Papéis Avulsos do Zoologia 49: 319-337.

Martins, M. 1993. Why do snakes sleep on the vegetation in central Amazonia? Herpetological Review 24: 83-84.

McCrainie, J.R. 2011. Snakes of Honduras. Systematics, Distribution, and Conservation. Society for the Study of Amphibians and Reptiles, Ithaca, New York.

Nogueira, C.H., C.A. Figueiredo-de-Andrade, and N. Freitas. 2013. Death of a juvenile snake Oxyrhopus petolarius (Linnaeus, 1758) after eating an adult house gecko Hemidactylus mabouia (Moreau de Jonnés, 1818). Herpetology Notes 6: 39-43. 
Rodrigues-França, F.G. and R. Amorim. 2012. First record of predation on the bat Carollia perspicillata by the False Coral Snake Oxyrhopus petolarius in the Atlantic Rainforest. Biotemas 25: 307-309.

Vitt, L.J. and J.P. Caldwell. 2014. Herpetology: An Introductory Biology of Amphibians and Reptiles. 4th ed. Academic Press, San Diego, California.

Vitt, L.J. and M.C. Carvalho. 1995. Niche partitioning in the wet season: Lizards in the lavrado area of northern Brazil. Copeia 1995: 305-329.

Vitt, L.J. and G.R. Colli. 1994. Geographical ecology of a Neotropical lizard: Ameiva ameiva (Teiidae) in Brazil. Canadian Journal of Zoology 72: 19862008.

Vitt, L.J. and P.A. Zani. 1996. Ecology of the lizard Ameiva festiva (Teiidae) in southeastern Nicaragua. Journal of Herpetology 30: 110-117. 